\title{
Developing Brand Loyalty through Consumer Engagement with Brand Communities in Social Media
}

\section{Jee-Sun Park}

Department of Fashion Industry, Incheon National University, Incheon, South Korea

\section{Sejin Ha}

Department of Retail, Hospitality, and Tourism Management, University of Tennessee, TN, USA

Keywords: Brand Community Engagement, Social Media, Brand Loyalty, Involvement. 


\section{Introduction}

Consumer engagement has become central in understanding how people interact with and behave in response to dynamic communications (Brodie et al., 2013; Verhoef et al., 2010). Generally, engagement is defined as being "involved, occupied, and interested in something" (Higgins, 2006). As O'Brien and Toms (2008) noted, "successful technologies are not just usable; they engage users" (p. 938) and thus engagement is critical to the success of technology-mediated communications like social media (Brodie et al., 2013). In practice, social media holds great potential for businesses that $54 \%$ of internet users use social media to search for products and services (Beer, 2018), among which $54 \%$ of Generation $\mathrm{Z}$ and $49 \%$ of millennial's use social media as their preferred advertising channel (Pitneybowes.com, 2019). Indeed, 73\% of marketers find social media marketing effective for business (buffer.com, 2019) while firms observe such benefits as improved relationships with customers and brand sales (McLachlan, 2020). Given the benefits, marketers put great effort in strategies to differentiate theirs from others; one strategy is on how to boost consumers' engagement on the community. Without engagement, social media is just another media. It is thus important to update the current understanding of consumer engagement with brand-hosted social media. There is ample evidence in the social media literature that consumer participation and engagement in brand-hosted social media leads to positive outcomes such as brand trust (Brodie et al., 2013; Hollebeek, 2011; So et al., 2016); satisfaction (Bowden, 2009; Wirtz et al., 2013); commitment (Bowden, 2009; Wirtz et al., 2013); consumer empowerment (Brodie et al., 2013); emotional bonding (Brodie et al., 2013); loyalty (Islam and Rahman, 2017; Vivek et al., 2012); self-brand connection (Harrigan et al., 2018; Hollebeek et al., 2014); relationship quality (So et al., 2016); Word-of-Mouth (WOM) (Halaszovich and Nel, 2017; Islam and Rahman, 2016); and brand performance (Wong and Merrilees, 2015).

Nevertheless, some limitations are identified in the literature on consumer engagement in social media. The first issue pertains to the inconsistent conceptualization of consumer engagement in social media. While many studies have considered engagement as a uni-dimensional construct (Gummerus et al., 2012; Jahn and Kunz, 2012; Laroche et al., 2012; Simon et al., 2016; Tafesse, 2016), recent research has argued it is more than a unidimensional concept (Brodie et al., 2011; 2013; Hollebeek et al., 2014). For example, Brodie and his colleagues $(2011$; 2013) developed a conceptual model of consumer engagement in which consumer engagement is comprised of cognitive, affective and behavioral constructs. Different conceptualizations invite further empirical investigation.

The second issue is the lack of research into consumer engagement specific to brandhosted social media. To date, research has predominantly focused on consumer engagement with brands (Halaszovich and Nel, 2017; Harrigan et al., 2018; Hollebeek, 2011). Consumer engagement research within brand-hosted social media has only just begun to emerge (Islam and Rahman, 2016; Simon et al., 2016).

The last issue concerns the importance of understanding of what drives consumer engagement and further performance of social media (Brodie et al., 2013; Hollebeek et al., 2014). One of the key determinants proposed by previous research is consumer involvement (Bowden, 2009; Hollebeek et al., 2014; Vivek et al., 2012). However, prior research heavily focused on brand involvement ignoring the impact of product 
involvement on consumer engagement. Consumers visit a particular brand page not only when they are fans of brands but also when they are interested in the product category (e.g., fashion items). Therefore, this study focuses on two types of involvement (brand and product involvement) in the process of consumer engagement with brand-hosted social media.

This study aims to address the aforementioned issues by developing and testing a research model of consumer engagement with brand-hosted social media communities. Specifically, the study posits that consumer engagement is multi-dimensional, embracing cognitive, affective and behavioral sub-constructs, as conceptualized by Brodie et al. $(2011 ; 2013)$ and intends to empirically validate the three-dimensional model. The present study also intends to provide a holistic understanding of how consumer involvement in brand and/or product can aid consumer engagement which in turn contributes to brand loyalty.

\section{Literature Review}

\section{Brand-hosted Brand Communities in Social Media}

A brand community is a specialized community around a particular brand and members who like the brand and/or the branded product category (McAlexander et al., 2002; Muniz and O'Guinn, 2001; Ouwersloot and Odekerken-Schröder, 2008). Originating from the traditional offline format, the brand community has evolved into a platform where marketers and consumers share a wide range of information, opinions, knowledge and interests surrounding the brand and its products (Muniz and O'Guinn, 2001; Ouwersloot and Odekerken-Schröder, 2008).

A brand-hosted brand community in social media (hereafter called brand-hosted social media) is a special form of online brand community (Laroche et al., 2012). Particularly, brand communities in social media have attracted a great deal of interest among businesses because of their unique advantages. Unlike offline brand communities, which require a high degree of commitment in terms of members' time, cost and location constraints, online brand communities with flexibility in time and location demand little or no cost to join (Wirtz et al., 2013). These benefits have attracted businesses to turn to social media as an additional brand community venue. Empirical findings proved that brand-hosted social media have a greater number of consumers with a wider range of involvement levels than traditional offline brand communities (Wirtz et al., 2013; Zaglia, 2013).

Brand-hosted social media can only be successful when members frequently visit communities and engage with brand posts, peer consumers and brand-related members. Active engagement can be various types of behaviors (Wirtz et al., 2013), including posting new comments and feedback on existing postings to share consumption experiences, give feedback to the firms, and help other consumers (Nambisan and Baron, 2009; Tafesse, 2016; Wirtz et al., 2013). In addition, passive engagement by consumers (e.g., reviewing contents and using hash tags or forwarding existing comments to share) is also common in social media. Research has proven that facilitating consumer engagement in communities in social media is critical for engendering brand loyalty (Shang et al., 2006). 


\section{Community Engagement with Brand-hosted Communities in Social Media}

A highly engaged state refers to a situation in which an individual concentrates on something with an intrinsic motivation for an activity (Higgins, 2006; O'Brien and Toms, 2008). As listed in Table 1, consumer engagement has been studied using various terms such as customer/consumer engagement, customer engagement behavior, customer/consumer brand engagement, online engagement and community engagement with various engagement objects. These objects include a brand, a firm's service, and marketing media (e.g., a firm's website and a mobile application, a brand community, an online brand community). The literature on engagement can be summarized in four points.

First, engagement is a valenced psychological state. While some conceptualize engagement focusing on the behavioral perspective (e.g., Gummerus et al., 2012; Laroche et al., 2012) or the experiential motivations (Calder et al., 2009), the literature largely supports the concept as a psychological state with motivation (Bowden, 2003; Brodie et al., 2011, 2013; Dessart et al., 2015, 2016; Hollebeek et al., 2014; 2016). Second, consumer engagement is centered on a consumer's interactive experiences, through which the consumer's motivational state towards a certain brand, a community, a brand's website or a brand's mobile application is facilitated. The notion that interactive experiences foster engagement becomes especially important when consumers engage with objects via technologies (e.g., brand-hosted social media) (O'Brien and Toms, 2008). Third, no consensus over the dimensionality of engagement has been made. Typically, researchers viewed engagement as a single dimension of behavior (Laroche et al., 2012) or a second-order factor manifested by psychological and behavioral engagement (Islam and Rahman, 2016). Then, studies (Brodie et al., 2011; Hollebeek et al., 2014) proposed a three-dimensional conceptual model in which engagement consists of cognitive, affective and behavioral aspects. Increasingly, the three-dimensional model is gaining support over the unidimensional model (Brodie et al., 2011; Brodie et al., 2013; Hollebeek et al., 2016; Hollebeek et al., 2014). Fourth, studies agree that consumer engagement plays a central role in the iterative process of consumers' relations with an object (e.g., a brand, a community) and is driven by individuals' internal motivations and contextual factors (Algesheimer et al., 2005; Islam and Rahman, 2017; Jahn and Kunz, 2012). Further, engagement leads to diverse outcomes such as co-creation value (Brodie et al., 2011; Brodie et al., 2013) and consumer loyalty beyond purchase (Bowden, 2009; Van Doorn et al., 2010).

Based on a review of the literature, this study defines consumer engagement with brandhosted communities in social media as a consumer's psychological state resulting from his/her cognitive, affective and behavioral interactions with a brand's community in social media. 
Table 1: Definition and Dimensionality of Engagement in Previous Research

\begin{tabular}{|c|c|c|c|}
\hline $\begin{array}{l}\text { Study/ } \\
\text { method }\end{array}$ & $\begin{array}{c}\text { Engagement } \\
\text { object }\end{array}$ & Definition & Dimensions \\
\hline \multicolumn{4}{|c|}{ Engagement with a brand } \\
\hline $\begin{array}{l}\text { Bowden } \\
(2009) \\
\text { qualitative }\end{array}$ & brand & $\begin{array}{l}\text { "a psychological process that models the underlying mechanisms by } \\
\text { which customer loyalty forms for new customers of a service brand as } \\
\text { well as the mechanisms by which loyalty may be maintained for repeat } \\
\text { purchase customers of a service brand" (p. } 65)\end{array}$ & $\begin{array}{l}\text { Unidimensional: } \\
\text { engagement process }\end{array}$ \\
\hline $\begin{array}{l}\text { Van Doorn } \\
\text { et al. }(2010) \\
\text { conceptual }\end{array}$ & brand/firm & $\begin{array}{l}\text { "behavioral manifestations that have a brand or firm focus, beyond } \\
\text { purchase, resulting from motivational drives" (p. 253) }\end{array}$ & $\begin{array}{l}\text { Multidimensional (Behavior focus): } \\
\text { 1. valence; } 2 \text {. form or modality; } 3 \text {. scope; } 4 \text {. nature of its impact; } 5 . \\
\text { customer goals }\end{array}$ \\
\hline $\begin{array}{l}\text { Hollebeek et } \\
\text { al. (2014); } \\
\text { empirical }\end{array}$ & brand & $\begin{array}{l}\text { a "consumer's positively valenced brand-related cognitive, emotional, } \\
\text { and behavioral activity during or related to focal consumer/brand } \\
\text { interactions" (p.154) }\end{array}$ & $\begin{array}{l}\text { Multidimensional: } \\
\text { 1. cognitive processing (C); 2. affection (A); 3. action (B) }\end{array}$ \\
\hline $\begin{array}{l}\text { Sarkar and } \\
\text { Sreejesh } \\
\text { (2014); } \\
\text { empirical }\end{array}$ & brand & $\begin{array}{l}\text { "the degree to which the individual is willing to spend time, energy, } \\
\text { money and other resources in the brand beyond those expended during } \\
\text { actual purchase or consumption of the brand" (p. 26) }\end{array}$ & $\begin{array}{l}\text { Unidimensional: } \\
\text { active engagement (B) }\end{array}$ \\
\hline $\begin{array}{l}\text { So et al. } \\
(2016) \\
\text { empirical }\end{array}$ & brand & $\begin{array}{l}\text { "a personal connection to a brand as manifested in cognitive, affective } \\
\text { and behavioral responses outside of the purchase" (p. 173) }\end{array}$ & $\begin{array}{l}\text { Multidimensional: } \\
\text { 1. identification (C); 2. enthusiasm (A); 3. attention (C); } 4 \text {. } \\
\text { absorption (C); 5. interaction (B) }\end{array}$ \\
\hline \multicolumn{4}{|c|}{ Engagement with a firm's offerings } \\
\hline $\begin{array}{l}\text { Vivek et al. } \\
(2012) \\
\text { qualitative }\end{array}$ & $\begin{array}{l}\text { a firm's } \\
\text { offering }\end{array}$ & $\begin{array}{l}\text { "the intensity of an individual's participation and connection with the } \\
\text { organization's offerings and activities initiated by either the customer } \\
\text { or the organization" (p. 133) }\end{array}$ & $\begin{array}{l}\text { Multidimensional: } \\
\text { 1. cognitive element (C); 2. emotional element (A); 3. behavioral } \\
\text { (B); 4. social (S) }\end{array}$ \\
\hline \multicolumn{4}{|c|}{ Engagement with a brand community } \\
\hline $\begin{array}{l}\text { Algesheimer } \\
\text { et al. }(2005) \text {; } \\
\text { empirical }\end{array}$ & $\begin{array}{l}\text { offline brand } \\
\text { community }\end{array}$ & $\begin{array}{l}\text { "consumer's intrinsic motivation to interact and cooperate with } \\
\text { community members" (p.21) }\end{array}$ & $\begin{array}{l}\text { Unidimensional: } \\
\text { community engagement }(\mathrm{B})\end{array}$ \\
\hline $\begin{array}{l}\text { Laroche } e t \\
\text { al. }(2012) \\
\text { empirical }\end{array}$ & $\begin{array}{l}\text { social media } \\
\text { based brand } \\
\text { community }\end{array}$ & $\begin{array}{l}\text { "the process of working collaboratively with relevant partners who } \\
\text { share common goals and interests" (p.1758) }\end{array}$ & $\begin{array}{l}\text { Unidimensional: } \\
\text { community engagement (B) }\end{array}$ \\
\hline $\begin{array}{l}\text { Jahn and } \\
\text { Kunz (2012); }\end{array}$ & $\begin{array}{l}\text { brand fan } \\
\text { page }\end{array}$ & $\begin{array}{l}\text { "persistent, positive, affective-motivational state of fulfillment" (pp. } \\
348-349 \text { ) }\end{array}$ & $\begin{array}{l}\text { Unidimensional: } \\
\text { fan page engagement }(\mathrm{B})\end{array}$ \\
\hline
\end{tabular}




\begin{tabular}{|c|c|c|c|}
\hline \multicolumn{4}{|l|}{ empirical } \\
\hline $\begin{array}{l}\text { Brodie et al. } \\
(2013) \text {; } \\
\text { qualitative }\end{array}$ & $\begin{array}{l}\text { virtual brand } \\
\text { community }\end{array}$ & $\begin{array}{l}\text { "A multidimensional concept comprising cognitive, emotional, and/or } \\
\text { behavioral dimensions, and plays a central role in the process of } \\
\text { relational exchange" (p. 107). }\end{array}$ & $\begin{array}{l}\text { Multidimensional: } \\
\text { 1. cognitive (C); 2. emotional (A); 3. behavioral (B) }\end{array}$ \\
\hline $\begin{array}{l}\text { Wirtz et al. } \\
(2013) \text {; } \\
\text { conceptual }\end{array}$ & $\begin{array}{l}\text { online brand } \\
\text { community }\end{array}$ & $\begin{array}{l}\text { "An identification with the OBC that results in interactive participation } \\
\text { in the OBC" (p. 230). }\end{array}$ & $\begin{array}{l}\text { Unidimensional: } \\
\text { participation behavior }(\mathrm{B})\end{array}$ \\
\hline $\begin{array}{l}\text { Simon et al. } \\
(2016) \text {; } \\
\text { empirical }\end{array}$ & $\begin{array}{l}\text { Facebook } \\
\text { brand page }\end{array}$ & $\begin{array}{l}\text { "a consumer's behavioral manifestations, such as sharing and } \\
\text { socializing with the online brand community on Facebook" (p. 409) }\end{array}$ & $\begin{array}{l}\text { Unidimensional: } \\
\text { brand community engagement }(\mathrm{B})\end{array}$ \\
\hline $\begin{array}{l}\text { Barger et al. } \\
(2016) \text {; } \\
\text { conceptual }\end{array}$ & social media & $\begin{array}{l}\text { "a set of measurable actions that consumers take on social media in } \\
\text { response to brand-related content" (p. 270) }\end{array}$ & $\begin{array}{l}\text { Unidimensional: } \\
\text { a set of measurable actions }\end{array}$ \\
\hline $\begin{array}{l}\text { Tafesse } \\
(2016) \\
\text { empirical }\end{array}$ & $\begin{array}{l}\text { Facebook } \\
\text { brand page }\end{array}$ & $\begin{array}{l}\text { "standardized response metrics, such as brand post "likes" and brand } \\
\text { post "shares" (p. 425) }\end{array}$ & $\begin{array}{l}\text { Multidimensional: } \\
\text { brand post likes (B); brand post shares (B) }\end{array}$ \\
\hline \multicolumn{4}{|c|}{ Engagement with media } \\
\hline $\begin{array}{l}\text { Calder et al. } \\
(2009) \\
\text { empirical }\end{array}$ & $\begin{array}{l}\text { brand's } \\
\text { website }\end{array}$ & "The overall experiences of a vehicle" (p.322). & $\begin{array}{l}\text { Multidimensional: } \\
\text { ( } 2^{\text {nd }} \text {-order construct): } 1 \text {. personal engagement } \\
\text { (stimulation/inspiration, social facilitation, temporal, self- } \\
\text { esteem/civic-mindedness, intrinsic enjoyment, utilitarian); } 2 \text {. social- } \\
\text { interactive engagement (participating/socializing, community) }\end{array}$ \\
\hline $\begin{array}{l}\text { Harrigan et } \\
\text { al. }(2018) \\
\text { empirical }\end{array}$ & $\begin{array}{l}\text { brand's } \\
\text { website }\end{array}$ & $\begin{array}{l}\text { "a consumer's cognitive, emotional, and behavioral activity around } \\
\text { specific consumer/brand interactions" (p. 388) }\end{array}$ & $\begin{array}{l}\text { Multidimensional: } \\
\text { 1. cognitive processing }(\mathrm{C}) ; 2 \text {. affection }(\mathrm{A}) ; 3 \text {. action }(\mathrm{B})\end{array}$ \\
\hline \multicolumn{4}{|c|}{ Engagement with multiple objects } \\
\hline $\begin{array}{l}\text { Dessart et al. } \\
(2015) \\
\text { qualitative }\end{array}$ & $\begin{array}{l}\text { Brand and } \\
\text { brand } \\
\text { community }\end{array}$ & $\begin{array}{l}\text { "a cognitive, affective, and behavioral commitment to an active } \\
\text { relationship with the brand" (p. } 30)\end{array}$ & $\begin{array}{l}\text { Multidimensional: } \\
\text { 1. affective (enthusiasm, enjoyment); } 2 \text {. cognitive (attention, } \\
\text { absorption); 3. behavioral (sharing, learning, endorsing) }\end{array}$ \\
\hline $\begin{array}{l}\text { Dessart et al. } \\
(2016) ; \\
\text { empirical }\end{array}$ & $\begin{array}{l}\text { Brand and } \\
\text { brand } \\
\text { community }\end{array}$ & $\begin{array}{l}\text { "a psychological state that occurs by virtue of interactive, co-creative } \\
\text { customer experiences with a focal agent/object (e.g., a brand) in focal } \\
\text { service relationships" (p. 399) }\end{array}$ & $\begin{array}{l}\text { Multidimensional: } \\
\text { 1. affective (enthusiasm, enjoyment); } 2 \text {. cognitive (attention, } \\
\text { absorption); } 3 \text {. behavioral (sharing, learning, endorsing) }\end{array}$ \\
\hline
\end{tabular}

Note: (C) denotes cognitive dimension; (A) denotes affective dimension; (B) denotes behavioral dimension; (S) denotes social dimension 


\section{Research Model of Consumer Engagement with Brand-hosted Brand Communities in Social Media}

In order to explore how consumer engagement works in a brand-hosted social media, this study first scrutinize consumer engagement within this specific interactive setting. In doing so, the three-dimensional conceptualization is deemed to be a comprehensive explanatory framework relative to a unidimensional model (Brodie et al., 2011; Hollebeek et al., 2016; Oliveria \& Fernandes, 2020). Therefore, the focus is on three aspects of engagement: cognitive, affective and behavioral engagement. First, cognitive engagement refers to one's level of cognitive attention and immersion during the interaction with brand-hosted social media. High engagement requires a state of attention and absorption (Dessart et al., 2016), immersion (Hollebeek, 2011) and sustained cognitive processing (Halaszovich and Nel, 2017; Hollebeek et al., 2014; Mollen and Wilson, 2010) during interactions with an engagement object. As consumers' interactions with brand-hosted social media intensify, they are likely to be focused and immersed in what they are doing during interactions.

Second, affective engagement concerns one's level of positively valenced feeling that occurs during his/her interaction with the brand-hosted social media. Previous research has validated that the affective aspect plays an important part of engagement (Apenes Solem, 2016; Dessart et al., 2016; Harrigan et al., 2018; So et al., 2016). Engaged consumers feel pleased and happy during the interaction (Dessart et al., 2016; Hollebeek et al., 2014), passionate (Hollebeek, 2011), and are intrinsically excited (Dessart et al., 2016) during the interaction.

Third, behavioral engagement is defined as the extent of one's level of effort and time spent on interacting with the engagement objects (Hollebeek, 2011; Hollebeek et al., 2014; Vivek et al., 2012). Behavioral engagement means doing tasks such as visiting and participating in community activities, paying attention to brand posts, sharing personal opinions/contents, helping others (Wirtz et al., 2013). In the setting of online brand communities, consumer participation and contribution to the community enhance interactivity between consumers and brands and engagement with the community (Wirtz et al., 2013).

In social media environments, where instant interactivity and easy connection with other platforms through hash tags are available, enhancing cognitive, affective and behavioral engagement is especially important for fostering brand-consumer relationships (Apenes Solem, 2016; Laroche et al., 2012). Using consumer engagement conceptualized as above, this study now turns to its potential determinants and consequences specific to brand communities in social media.

\section{The Antecedent Role of Brand and Product Involvement}

This study argues that consumer engagement with a brand's social media community begins from a consumer's personal motivation for being or becoming interested in something related to the context. Involvement captures a consumer's intrinsic motivational status regarding an object (Celsi and Olson, 1988; Zaichkowsky, 1985). It is well-established that people attach personal relevance and importance towards such objects as brand, product and community (e.g., Vivek et al., 2012). Involvement also plays a role across varying stages of consumption including the pre-consumption stage 
(Zaichkowsky, 1985) as well as different contexts including consumer information processing (Beatty and Smith, 1987; Mathwick and Rigdon, 2004), consumer experiences (Novak et al., 2003; Novak et al., 2000) and brand engagement (Hollebeek et al., 2014; So et al., 2016).

This study focuses on two kinds of involvement: brand involvement and product involvement. These aspects of involvement are considered to be the most powerful forces in consumer behavior (Ouwersloot and Odekerken-Schröder, 2008). First, brand involvement refers to the degree to which a consumer finds a certain brand interesting and relevant to him/her. Unsurprisingly, brand is the core focus of a brand community (Carlson et al., 2008; Muniz and O'Guinn, 2001; Wirtz et al., 2013). Brand involvement has a significant impact on a variety of activities in a brand community, including its fans sharing their brand-related stories and information, developing traditions of the brand (Muniz and O'Guinn, 2001), and engaging with the community (Schau et al., 2009). When consumers encounter a certain brand that they consider important, their intrinsic motivation toward the brand will stimulate cognitive, affective and behavioral exploration of the brand's communication (e.g., the brand community in social media) (Vivek et al., 2012). In the setting of brand-hosted communities in social media, consumers are more likely to devote their energy, attention and time to being in the community when the brand is important and meaningful (Gómez et al., 2019; Oliveria \& Fernandes, 2020). That is, they would be more interested in checking new products and promotions, reviewing new ads featured in photos and videos, and interacting with the brand and other community members by liking and/or leaving comments.

H1 Brand involvement positively influences consumer engagement (a: cognitive, b: affective, c: behavioral engagement) with the brand community in social media.

Even when having little or no interest in a brand, consumers may still be interested in connecting with a brand's community if they find it useful for product information. Product involvement refers to the degree to which a product category (i.e., fashion and clothing in this study) means to the consumer. In the traditional marketing literature, high levels of involvement with a product category have been found to be associated with extensive search for product information (Beatty and Smith, 1987), and increased behavioral intentions (Beatty and Smith, 1987; Vivek et al., 2012).

The literature on social media has also reported consistent results regarding the role of product involvement on consumers in virtual worlds (Ouwersloot and OdekerkenSchröder, 2008; Nambisan and Baron, 2009). Highly interested fashion consumers would have greater potential to enjoy and commit to a focal brand community because of their higher degree of curiosity about fashion products, greater ability to find out intricate features of the products and heightened involvement in mental simulation (Mathwick and Rigdon, 2004; Nambisan and Baron, 2007). When a brand's community in social media delivers posts conveying new fashion trends, outfit of the day ideas, product information and consumption-related experiences coupled with influencers of interest to visitors, such environment reinforces their positive thinking, feelings and engaging participation in favor of the brand (Muniz and O'Guinn, 2001; Nambisan and Baron, 2009; Wang \& Lee, 2020). Furthermore, a greater chance for mutual exchanges and understanding of product-related issues among members (Algesheimer et al., 2005) intensifies the 'consciousness of kind' (McAlexander et al., 2002). 
$\mathrm{H} 2$ Product involvement positively influences the consumer's engagement (a: cognitive, b: affective, c: behavioral engagement) with the brand community in social media.

\section{Brand Loyalty}

A relevant and favorable relationship with customers is a key precursor for the establishment of trust and commitment which further enhances loyalty (Morgan and Hunt, 1994). This study focuses on brand loyalty as an outcome of consumers' engagement with brand-hosted social media. Brand loyalty is defined as a 'deeply held commitment to rebuy or repatronize a preferred product/service consistently in the future, thereby causing repetitive same-brand or same brand-set purchasing, despite situational influences and marketing efforts having the potential to cause switching behavior' (Oliver, 1999). It thus represents attitudinal and behavioral preferences for a brand over alternatives (Dick and Basu, 1994).

As a way to enhance consumer brand loyalty and company-consumer long-term relationships, many companies are paying attention to brand communities where active consumer engagement occurs (e.g., Carlson et al., 2008; McAlexander et al., 2002; Schau et al., 2009). Likewise, research has shown that consumer engagement results in more than mere transactions of a brand, but can be a strategic advantage that brings consumer loyalty (Brodie et al., 2013; Laroche et al., 2012). Specifically, brand loyalty is preceded by various precursors such as brand trust (Laroche et al., 2013), brand community commitment (Luo et al., 2015), and consumer brand engagement with subdimensions of cognitive, affective and behavioral engagement (Helme-Guizon and Magnoni, 2019; Liu et al., 2019).

This study proposes that brand-hosted social media also can be a powerful channel for building brand loyalty through consumers' engagement with its community (Jahn and Kunz, 2012; Laroche et al., 2012). With more accumulated knowledge and experiences gained through active engagement, consumers feel close and bonded with the brand (Wang \& Lee, 2020). Specifically, as consumers more actively participate and engage in a brand's online community, they will find their interactive experiences with and values from continued interactions with the brand community meaningful, which together, will lead them to be loyal (Algesheimer et al., 2005; Wirtz et al., 2013).

H3 The consumer's engagement (a: cognitive, b: affective, c: behavioral engagement) with a brand community in social media positively influences brand loyalty.

\section{Methodology}

\section{Data Collection}

This study used a web-based survey method for data collection. A population of interest was those who actively used various social media platforms including social media accounts of fashion brands. This study focused on young Korean consumers aged between 21 and 49 years old who followed at least one fashion brand fan page in social media for the following reasons: First, in 2020, South Korea ranked third globally with 
$87 \%$ social media usage penetration (Statista, 2020a). Second, across the world, young generations including Generation $\mathrm{Z}$ and millennial are heavy users of social media and highly attentive to retail marketing and advertising strategies compared to other generations (Pitneybowes.com, 2019). In South Korea, according to a 2019 survey, $86.9 \%$ of 20 s, $70.1 \%$ of 30 s and $55.2 \%$ of 40 s were actively using social media (Statista, 2020b).

Members of a consumer panel recruited by a professional service provider in South Korea participated in the survey. First, participants were briefly informed of the research and supplied with definitions of key terms (e.g., social media). Next, participants indicated names of fashion brand social media accounts they were following. From this, non-users were excluded from the survey. With one social media account they visited most recently in mind, participants completed a questionnaire based on their experiences with and evaluations of the account. A total of 364 valid responses were collected and used for data analysis.

\section{Measures}

The survey questionnaire comprised a series of questions designed to assess key research variables mainly in four sections: (1) consumer involvement in the brand and the brand's product category, (2) consumer engagement with the brand's community (cognitive, affective, and behavioral engagement), (3) loyalty intention towards the brand, and (4) demographic information. All measures were adapted from existing scales and the reliability and validity of each were confirmed in past research. Table 2 presents the measures. Brand involvement and product involvement, the degree to which one perceives the corresponding brand and fashion products to be important, were measured using ten semantic differential items on a seven-point semantic differential scale (Zaichowsky, 1994). Consumer engagement pertains to how the individual feels, thinks, and acts during their interaction with the fashion brand's social media account. A total of nine items were used to capture cognitive (Agarwal and Karahanna, 2000; Apenes Solem, 2016), affective (Hollebeek et al., 2014) and behavioral (Hollebeek et al., 2014) engagement. Brand loyalty, the individual's level of commitment to keep their business with the brand in the future, was assessed using three items adopted from Labrecque (2014). Consumer engagement and brand loyalty were measured on a seven-point Likert scale ( $1=$ strongly disagree; $7=$ strongly agree). In order to develop a questionnaire in Korean for participants, a translation-back translation process was applied.

\section{Results}

\section{Sample Characteristics}

The mean age of the respondents was 33 years old, and $49.5 \%$ were male. The respondents were fairly well-educated with $81.9 \%$ indicating that they had completed a university degree or above. As for usage of social networking sites, respondents expressed that they were using Facebook (80.8\%), Instagram (87.6\%), Kakao Story (36.0\%), Twitter (26.1\%), and Pinterest (7.7\%). 


\section{Data Analyses}

Table 2: Measurement Scales

\begin{tabular}{|c|c|c|c|}
\hline Variable & $\begin{array}{l}\text { Factor } \\
\text { loading }\end{array}$ & $\begin{array}{c}\text { Cronbach's } \\
\alpha\end{array}$ & $\begin{array}{l}\text { Construct } \\
\text { reliability }\end{array}$ \\
\hline \multicolumn{4}{|l|}{ Brand involvement (The brand is...) } \\
\hline unimportant/important * & - & 0.87 & 0.86 \\
\hline irrelevant/relevant & 0.67 & & \\
\hline means nothing to me/means a lot to me & 0.83 & & \\
\hline worthless/valuable & 0.76 & & \\
\hline boring/interesting & 0.56 & & \\
\hline unexciting/exciting* & - & & \\
\hline unappealing/appealing & 0.69 & & \\
\hline mundane/fascinating* & - & & \\
\hline uninvolving /involving* & - & & \\
\hline not needed/needed & 0.77 & & \\
\hline \multicolumn{4}{|l|}{ Product involvement (Fashion items are...) } \\
\hline unimportant/important* & - & 0.93 & 0.92 \\
\hline irrelevant/relevant & 0.83 & & \\
\hline means nothing to me/means a lot to me & 0.86 & & \\
\hline worthless/valuable & 0.88 & & \\
\hline boring/interesting & 0.76 & & \\
\hline unexciting/exciting* & - & & \\
\hline unappealing/appealing & 0.75 & & \\
\hline mundane/fascinating* & - & & \\
\hline uninvolving /involving* & - & & \\
\hline not needed/needed & 0.82 & & \\
\hline \multicolumn{4}{|l|}{$\begin{array}{l}\text { Cognitive engagement (While interacting } \\
\text { with this brand SNS ...) }\end{array}$} \\
\hline My attention did not get diverted. & 0.87 & 0.92 & 0.92 \\
\hline I was absorbed in what I was doing. & 0.91 & & \\
\hline $\begin{array}{l}\text { I was immersed in the task I was } \\
\text { performing. }\end{array}$ & 0.90 & & \\
\hline \multicolumn{4}{|l|}{ Affective engagement } \\
\hline I felt very positive. & 0.88 & 0.93 & 0.93 \\
\hline I enjoyed interacting with this brand SNS. & 0.89 & & \\
\hline I felt good with this brand SNS. & 0.93 & & \\
\hline \multicolumn{4}{|l|}{ Behavioral engagement } \\
\hline $\begin{array}{l}\text { I spent a lot of time using this brand SNS, } \\
\text { compared to others. }\end{array}$ & 0.85 & 0.88 & 0.88 \\
\hline $\begin{array}{l}\text { Whenever I was using SNS, I usually used } \\
\text { this brand SNS. }\end{array}$ & 0.90 & & \\
\hline $\begin{array}{l}\text { This brand SNS was one of what I usually } \\
\text { used. }\end{array}$ & 0.78 & & \\
\hline \multicolumn{4}{|l|}{ Brand loyalty } \\
\hline $\begin{array}{l}\text { I am willing to say positive things about } \\
\text { this brand to others. }\end{array}$ & 0.82 & 0.86 & 0.87 \\
\hline $\begin{array}{l}\text { I am willing to encourage close others to } \\
\text { do business with this brand. }\end{array}$ & 0.89 & & \\
\hline $\begin{array}{l}\text { I plan to do business with this brand in the } \\
\text { next few years. }\end{array}$ & 0.78 & & \\
\hline
\end{tabular}

Note: $*$ denotes deleted item 
Data analyses were administered in two phases (Anderson and Gerbing, 1988). First, confirmatory factor analysis (CFA) was performed in order to ensure the quality of the proposed measurement model. Second, structural equation modeling was conducted to test the proposed hypotheses. Both analyses were performed with Amos 23.0 using maximum likelihood estimation of the covariance matrix.

To verify the fit of the measurement model, properties of the measurement model including Cronbach's alpha, construct reliability, convergent validity and discriminant validity were examined. Cronbach's alpha and construct reliability are two common internal consistency indexes. CFA was performed with all factors for the measurement model. After deleting four items from each brand involvement and product involvement due to the low factor loadings, the re-specified measurement model exhibited acceptable model fit statistics $\left(\chi 2=439.89, \mathrm{df}=231, \chi^{2} / \mathrm{df}=1.90, \mathrm{p}<0.001, \mathrm{CFI}=\right.$ $0.97, \mathrm{TLI}=0.96, \mathrm{IFI}=0.97, \mathrm{RMSEA}<0.05, \mathrm{SRMR}=0.04)$. All coefficients were significant. As a result, the respecified model suggested an acceptable fit of the model to the data (Hair et al., 2019). As presented in Tables 2 and 3, the measurement model demonstrated support for internal reliability, convergent validity, and discriminant validity. The Average Variance Extracted (AVE) of all constructs were greater than the threshold value of 0.50 (Fornell and Larcker, 1981). In addition, the AVE of each construct was greater than the shared variances (squared correlation coefficients) between all possible pairs of constructs (Fornell and Larcker, 1981).

Table 3: Average Variance Extracted and Squared Correlations

\begin{tabular}{lcccccc}
\hline & $\mathbf{1}$ & $\mathbf{2}$ & $\mathbf{3}$ & $\mathbf{4}$ & $\mathbf{5}$ & $\mathbf{6}$ \\
\hline $\begin{array}{l}\text { 1. Brand } \\
\text { involvement }\end{array}$ & $\mathbf{0 . 5 2}$ & & & & & \\
$\begin{array}{l}\text { 2. Product } \\
\text { involvement }\end{array}$ & 0.44 & $\mathbf{0 . 6 7}$ & & & & \\
$\begin{array}{l}\text { 3. Cognitive } \\
\text { engagement }\end{array}$ & 0.29 & 0.33 & $\mathbf{0 . 8 0}$ & & & \\
$\begin{array}{l}\text { 4. Affective } \\
\text { engagement }\end{array}$ & 0.35 & 0.45 & 0.47 & $\mathbf{0 . 8 1}$ & & \\
$\begin{array}{l}\text { 5. Behavioral } \\
\text { engagement }\end{array}$ & 0.37 & 0.37 & 0.47 & 0.58 & $\mathbf{0 . 7 1}$ & \\
6. Brand loyalty & 0.44 & 0.55 & 0.36 & 0.55 & 0.51 & $\mathbf{0 . 6 9}$ \\
\hline
\end{tabular}

Note: Diagonal entries are Average variances extracted (AVE) for each construct. Off-diagonal entries are the squared correlation coefficients between constructs.

Structural equation modeling was performed to test the proposed hypotheses. The results exhibited an adequate model fit $\left(\chi^{2}=639.41, d f=236, \chi^{2} / d f=2.71, \mathrm{CFI}=0.94\right.$, $\mathrm{TLI}=0.93, \mathrm{IFI}=0.94, \mathrm{RMSEA}<0.07, \mathrm{SRMR}=0.7)$, indicating that the model fits the data well. All hypotheses were supported. The model accounted for 44.1\%, 56.0\%, $52.5 \%$ and $60.9 \%$ of the variances in cognitive engagement, affective engagement, behavioral engagement and brand loyalty, respectively. The results are presented in Figure 1. 
Figure 1: Resulted Research Model

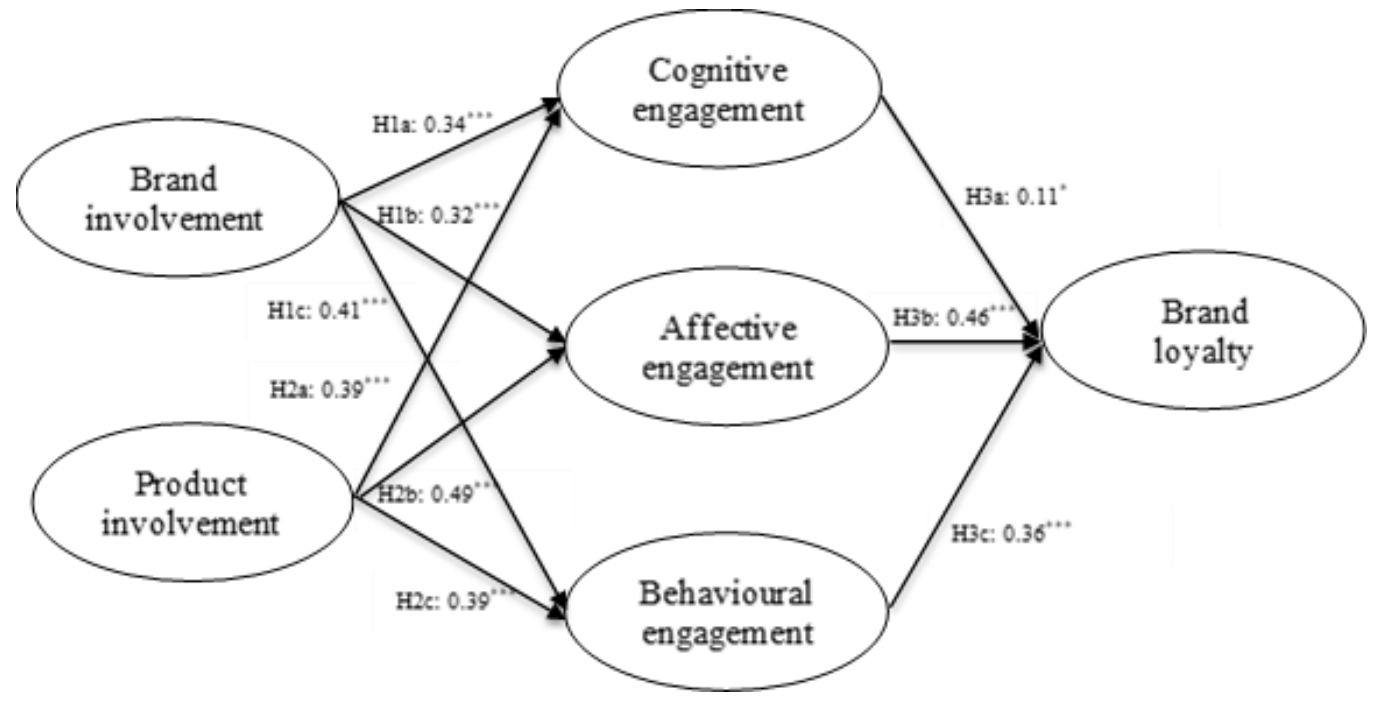

Note: standardized coefficients are reported. $* \mathrm{p}<0.05, * * * \mathrm{p}<0.001$

Hypotheses 1a-1c predicted the impacts of brand involvement on three dimensions of consumer engagement with brand-hosted social media. Analysis revealed that brand involvement significantly influences cognitive $(\beta=0.34, \mathrm{~b}=0.35, t$-value $=4.85, p<$ $0.001)$, affective $(\beta=0.32, \mathrm{~b}=0.32, t$-value $=5.14, p<0.001)$ and behavioral $(\beta=$ $0.41, \mathrm{~b}=0.47, t$-value $=5.92, p<0.001)$ engagement. Therefore, H1a, H1b, and H1c were supported. Hypotheses $2 \mathrm{a}-2 \mathrm{c}$ postulated the associations between product involvement and three dimensions of consumer engagement. Results showed that product involvement has a significantly positive impact on cognitive $(\beta=0.39, \mathrm{~b}=$ $0.43, t$-value $=5.74, p<0.001)$, affective $(\beta=0.49, \mathrm{~b}=0.52, t$-value $=7.85, p<0.001)$ and behavioral $(\beta=0.39, \mathrm{~b}=0.48, t$-value $=5.86, p<0.001)$ engagement, in support of $\mathrm{H} 2 \mathrm{a}, \mathrm{H} 2 \mathrm{~b}$, and $\mathrm{H} 2 \mathrm{c}$. Hypotheses $3 \mathrm{a}-3 \mathrm{c}$ predicted the impacts of three dimensions of consumer engagement on brand loyalty. Results revealed that loyalty intention is significantly influenced by cognitive $(\beta=0.11, \mathrm{~b}=0.10, t$-value $=2.11, p<0.05)$, affective $(\beta=0.46, \mathrm{~b}=0.45, t$-value $=8.28, p<0.001)$ and behavioral $(\beta=0.31, \mathrm{~b}=$ $0.36, t$-value $=6.42, p<0.001$ ) engagement, yielding support for $\mathrm{H} 3 \mathrm{a}, \mathrm{H} 3 \mathrm{~b}$ and $\mathrm{H} 3 \mathrm{c}$. An overview of the hypothesis testing is presented in Table 4. 
Table 4: Results of the Structural Model

\begin{tabular}{lccc}
\hline Hypotheses & $\begin{array}{c}\text { Standardized } \\
\text { Coefficient }\end{array}$ & $\mathbf{9 0 \%}$ CI & $\boldsymbol{t}$-value \\
\hline H1a: BI $\rightarrow$ CE & 0.34 & {$[0.14,0.53]$} & $4.85^{* * * *}$ \\
H1b: BI $\rightarrow$ AE & 0.32 & {$[0.14,0.51]$} & $5.14^{* * * *}$ \\
H1c: BI $\rightarrow$ BE & 0.41 & {$[0.21,0.61]$} & $5.92^{* * * *}$ \\
H2a: PI $\rightarrow$ CE & 0.39 & {$[0.18,0.58]$} & $5.74^{* * *}$ \\
H2b: PI $\rightarrow$ AE & 0.49 & {$[0.32,0.66]$} & $7.85^{* * * *}$ \\
H2c: PI $\rightarrow$ BE & 0.39 & {$[0.16,0.58]$} & $5.86^{* * *}$ \\
H3a: CE $\rightarrow$ BL & 0.11 & {$[0.01,0.21]$} & $2.11^{*}$ \\
H3b: AE $\rightarrow$ BL & 0.46 & {$[0.25,0.61]$} & $8.28^{* * * *}$ \\
H3c: BE $\rightarrow$ BL & 0.31 & {$[0.21,0.54]$} & $6.42^{* * *}$ \\
\hline
\end{tabular}

Note: $* * * \mathrm{p}<0.001, * \mathrm{p}<0.05 . \mathrm{BI}=$ brand involvement, $\mathrm{PI}=$ product involvement, $\mathrm{CE}=$ cognitive engagement, $\mathrm{AE}=$ affective engagement, $\mathrm{BE}=$ behavioral engagement, $\mathrm{BL}=$ brand loyalty.

\section{Discussion}

With the limited amount of research attention that has been paid to central elements in the context of brand-hosted social media, the current study argued that consumer engagement is a key element to brand loyalty and confirmed the argument. Specifically, this study demonstrated that within the context of a brand-related social media, consumer engagement is characterized by three dimensions including cognitive, affective and behavioral engagement, all of which contribute to brand loyalty. The examination of path coefficients further suggested that, compared to cognitive engagement, affective and behavioral engagement is primary precursors of brand loyalty. In addition, this study offers evidence that consumer involvement is correlated with engagement in that both brand involvement and product involvement are key drivers of consumer engagement in brand-hosted social media.

\section{Theoretical Contributions}

The main theoretical contributions of this study are twofold. First, this study conceptualized and tested three dimensions of consumer engagement in the brandhosted social media setting. Extending the main contexts of consumer engagement in social media beyond brands (Halaszovich and Nel, 2017; Hollebeek et al., 2014; Pongpaew et al., 2017) and brand posts (Barger et al., 2016; Tafesse, 2016), this research confirms the presence of three-dimensions of engagement. The results provide empirical support for the conceptual models developed by Brodie et al. $(2011 ; 2013)$ and Hollebeek et al. (2014). Moreover, extant research has approached engagement as a second-order factor with affective, cognitive and behavioral engagement as first-order factors (e.g., Liu et al., 2019) or as a one key dimension instead of all three dimensions (e.g., behavioral engagement) (Gummerus et al., 2012; Tafesse, 2016; Wirtz et al., 2013). The results of this study emphasize that each of the three dimensions of engagement plays a central role in the process of community engagement and development of brand loyalty which helps to gain a comprehensive understanding of consumer engagement. The cognitive and affective aspects of engagement represent a consumer's level of immersive experiences and feelings during the interaction with a brand community; the behavioral aspect captures the time and effort spent by the consumer participating in the community. The findings provide support for the threedimensional model that has been widely discussed in brand engagement research (e.g., 
Halaszovich and Nel, 2017; Hollebeek et al., 2014; 2016) by verifying its applicability to consumer-brand community engagement in social media. A high value of the R2 for brand loyalty $(60.9 \%)$ also corroborates the claim that consumer community engagement is an effective measure of social media performance for brands (e.g., brand loyalty) (Hollebeek et al., 2014; Liu et al., 2019).

Second, this study demonstrated significant associations that community engagement has with brand involvement, product involvement and brand loyalty. This study contributes to the literature on consumer engagement by focusing on two types of consumer involvement (brand involvement, product involvement) as antecedents. Consistent with previous studies (Gómez et al., 2019; Oliveria \& Fernandes, 2020; Vivek et al., 2012), this study reveals that consumers who are more involved with a brand are more likely to engage with the brand. Although little research has focused on product involvement, this study has demonstrated that consumer engagement with brand-hosted social media can be boosted by product involvement. This suggests that fashion lovers who are new to a certain brand can be brand lovers and further advocates once they are enticed to and engaged with the brand's social media. Specifically, product involvement has a greater impact on the cognitive and affective engagement dimensions than brand involvement. In contrast, brand involvement has a greater impact on the behavioral dimension than product involvement. Such findings add support for the consumer engagement literature which highlights individual characteristics as facilitators of vital consumer engagement (e.g., Dessart, 2017). The results also contribute to the literature showing that the more consumers feel involved with the focal brand as well as the product category, the more likely they are to engage with the brand-hosted social media (Harrigan et al., 2018; Hollebeek et al., 2014; So et al., 2016; Vivek et al., 2012).

\section{Limitations and Future Research Directions}

Despite the contributions of this work to the existing literature, there are several limitations that offer ideas for future research. First, the use of a cross-sectional design limited the findings to consumer engagement at one time. Given the nature of engagement that occurs through iterative experiences, future research adopting a longitudinal design would be beneficial to describe the causal engagement process. Relatedly, second, as social media has been deeply penetrating into the lives of young generations, today's consumer engagement in social media may not be fully captured by Brodie et al. model (2013). For example, Shawky et al. (2020) recent conceptualization of consumer engagement underscores the multi-actor engagement which embraces connection, interaction, loyalty, and advocacy. Further insights into the current facets of consumer engagement on social media across different contexts would be necessary. Third, this study used a convenience sample in one country, which required caution in interpreting the results. Future research replicating this study in different countries in Asia Pacific would contribute to the generalization of the current findings. In doing so, it would be worthwhile to compare the model across different generations, gender and/or cultures. Forth, the current data was collected based on participants' experiences with their chosen brand-hosted communities in social media. Since brand communities can be varied in such characteristics as the number of fans (Simon et al., 2016), brand type (Barger et al., 2016), nature of connections and/or level of customization of messages (Buzeta et al., 2020), different brand-related social media and media platforms may activate different mechanisms driving engagement which 
merits further investigation. Lastly, this study relied on self-report data from social media users (i.e., self-reported engagement activities in brand-hosted social media). Future research could test the proposed model by applying different metrics of consumer engagement (e.g., 'Like, Comment, Share, React' from Swani and Labrecque, 2020, 'Consumption, Contribution, and Creation' from Buzeta et al., 2020).

\section{Implications for Asian Business}

In response to the presence of strong social media users and mobile phone penetration in Asia Pacific (Statista, 2020c), digital marketing has become one of key marketing strategies for managing brand communications and customer relationship management in Asian business. Indeed, social media stand as a retail channel for Asian consumers to search for and shop products and/or brands. However, despite the general consensus on the paramount significance of social media, how to effectively utilize the platform as leverage still remains a challenge. The findings from this paper can benefit marketers striving for effective digital marketing.

First, social media managers should design communication content in social media in ways that facilitate each dimension of consumer engagement with the community. Specifically, content management that helps consumers feel emotional connections in a given context (e.g., affective signals such as emoji, interpersonal communication tones) may be most powerful for generating loyalty towards the brand based on the finding that affective engagement has the greatest impact on brand loyalty. Similarly, social media pages should create digital experiences wherein consumers want to act and stay longer in brand communities. Up-to-date quality information about products and promotions, creative posts and fast feedbacks to consumer inquiries and comments would help consumers stay and explore more about what the brand communicates in its social media platform. Similarly, live streaming events hosted by brand advocates or influencers would help to stay in touch with customers. In addition, to encourage consumer engagement, social media marketers can also implement value-driven tactics and activities, such as providing incentives for comments and contents posted and/or shared by consumers, launching promotional events for consumer participation and granting consumer status levels which are particularly important to Asian consumers.

The findings that not only brand involvement but also product involvement lead to consumer engagement with the social media community emphasizes the importance of understanding the target customers' needs and preferences for products, promotions, and/or interpersonal communications. Such knowledge would be particularly important to brands in Asia Pacific market given dominant cultural characteristics of Asian consumers such as collectivism, high-power distance, and long-term orientation (Hofstede et al., 2010). For example, according to Lin et al. (2017) social media practice guidelines, social media posts highlighting the 'we' (vs. 'I'), functional information (vs. consumer identity), and one-way (vs. two-way) communication would be effective for collectivistic, high-power distance, and long-term oriented cultures, respectively. In brand-hosted social media, the more consumers find the brand, product, and/or promotion relevant to themselves, the more likely they are to engage in the brand's social media. Customer profiling and tracking customer journey enable brands to segment their target audience into a number of small profitable groups (i.e., social media personas) and tailor marketing contents to the need of each of the group. 
Moreover, based on the finding that product involvement has a stronger impact on cognitive and affective dimensions of engagement than brand involvement, brand managers may want to entice consumers who are interested in the brand's product category even if they have low involvement with the brand. Thus, an opportunity exists for brands, if they target and attract potential customers who like the product category, to initiate the engagement process. Perhaps, marketers can segment consumers based on consumer involvement in product categories and brands, from which they can customize digital contents on social media in a way that attracts salient engagement activities of each consumer segment.

Acknowledgements: This work was supported by Incheon National University Research Grant in 2019.

\section{References}

Agarwal, R. and Karahanna, E. (2000), "Time flies when you're having fun: Cognitive absorption and beliefs about information technology usage", MIS Quarterly, Vol. 24, No. 4, pp.665-694.

Algesheimer, R., Dholakia, U. M. and Herrmann, A. (2005), "The social influence of brand community: Evidence from European car clubs", Journal of Marketing, Vol. 69, No. 3, pp.19-34.

Anderson, J. C. and Gerbing, D. W. (1988), "Structural equation modeling in practice: A review and recommended two-step approach", Psychological Bulletin, Vol. 103, No. 3, pp.411-423.

Apenes Solem, B. A. (2016), "Influences of customer participation and customer brand engagement on brand loyalty", Journal of Consumer Marketing, Vol. 33, No. 5, pp.332-342.

Barger, V., Peltier, J. W. and Schultz, D. E. (2016), "Social media and consumer engagement: A review and research agenda", Journal of Research in Interactive Marketing, Vol. 10, No. 4, pp.268-287.

Beatty, S. E. and Smith, S. M. (1987), 'External search effort: An investigation across several product categories", Journal of Consumer Research, Vol. 14, No. 1, pp.83-95.

Beer, C. (2018), Social browers engage with brands, by GWI [online] https://blog.globalwebindex.com/chart-of-the-day/social-browsers-brand/ (accessed 27 March 2021).

Bowden, J. (2009), "Customer engagement: A framework for assessing customer-brand relationships: The case of the restaurant industry", Journal of Hospitality Marketing and Management, Vol. 18, No. 6, pp.574-596.

Brodie, R. J., Hollebeek, L. D., Jurić, B. and Ilić, A. (2011), "Customer engagement: Conceptual domain, fundamental propositions, and implications for research", Journal of Service Research, Vol. 14, No. 3, pp.252-271.

Brodie, R. J., Ilic, A., Juric, B. and Hollebeek, L. (2013), "Consumer engagement in a virtual brand community: An exploratory analysis", Journal of Business Research, Vol. 66, No. 1, pp.105-114.

Buffer.com (2019), State of social, bu Buffer [online] https://buffer.com/state-of-social-2019 (accessed 27 March 2021).

Calder, B. J., Malthouse, E. C. and Schaedel, U. (2009), "An experimental study of the relationship between online engagement and advertising effectiveness", Journal of Interactive Marketing, Vol. 23, No. 4, pp.321-331. 
Carlson, B. D., Suter, T. A. and Brown, T. J. (2008), "Social versus psychological brand community: The role of psychological sense of brand community", Journal of Business Research, Vol. 61, No. 4, pp. 284-291.

Dessart, L. (2017), "Social media engagement: A model of antecedens and relational oucomes", Journal of Marketing Management, Vol. 33, No. 5-6, pp. 375-399.

Dessart, L., Veloutsou, C. and Morgan-Thomas, A. (2015), "Consumer engagement in online brand communities: A social media perspective", Journal of Product \& Brand Management, Vol. 24, No. 1, pp.28-42.

Dessart, L., Veloutsou, C. and Morgan-Thomas, A. (2016), "Capturing consumer engagement: Duality, dimensionality and measurement.", Journal of Marketing Management, Vol. 32, No. 5-6, pp. 399-426.

Dick, A. S. and Basu, K. (1994), "Customer loyalty: Toward an integrated conceptual framework", Journal of the Academy of Marketing Science, Vol. 22, No. 2, pp. 99-113.

Fornell, C. and Larcker, D. F. (1981), "Evaluating structural equation models with unobservable variables and measurement error", Journal of Marketing Research, Vol. 18, No. 1, pp. 39-50.

Gómez, M., Lopez, C. and Molina, A. (2019), "An integrated model of social media brand engagement", Computers in Human Behavior, Vol. 96, pp. 196-206.

Gummerus, J., Liljander, V., Weman, E. and Pihlström, M. (2012), "Customer engagement in a Facebook brand community", Management Research Review, Vol. 35, No. 9, pp. 857-877.

Hair, J. F., Black, W. C., Babin, B. J. and Anderson, R. E. (2019), Multivariate Data Analysis, 8th ed., Cengage Learning EMEA, Andover, UK.

Halaszovich, T. and Nel, J. (2017), "Customer-brand engagement and Facebook fan-page "Like"intention", Journal of Product \& Brand Management, Vol. 26, No. 2, pp. 120-134.

Harrigan, P., Evers, U., Miles, M. P. and Daly, T. (2018), "Customer engagement and the relationship between involvement, engagement, self-brand connection and brand usage intent", Journal of Business Research, Vol. 88, pp. 388-396.

Helme-Guizon, A. and Magnoni, F. (2019), "Consumer brand engagement and is social side on brand-hosted social media: How do they contribute to brand loyalty?", Journal of Marketing Management, Vol. 35 No. 7-8, pp. 716-741.

Higgins, E. T. (2006), "Value from hedonic experience and engagement", Psychological Review, Vol. 113, No. 3, pp. 439-460.

Hofstede, G., Hofstede, G. J. and Minkov, M. (2010), Cultures and Organizations: Software of the Mind, 3rd ed., McGraw-Hill, New York, NY.

Hollebeek, L. (2011), "Exploring customer brand engagement: Definition and themes", Journal of Strategic Marketing, Vol. 19, No. 7, pp. 555-573.

Hollebeek, L. D., Conduit, J. and Brodie, R. J. (2016), "Strategic drivers, anticipated and unanticipated outcomes of customer engagement", Journal of Marketing Management, Vol. 32, No. 5-6, pp. 393-398.

Hollebeek, L. D., Glynn, M. S. and Brodie, R. J. (2014), "Consumer brand engagement in social media: Conceptualization, scale development and validation", Journal of Interactive Marketing, Vol. 28, No. 2, pp. 149-165.

Islam, J. U. and Rahman, Z. (2016), "Linking customer engagement to trust and word-of-mouth on Facebook brand communities: An empirical study", Journal of Internet Commerce, Vol. 15, No. 1, pp. 40-58.

Islam, J. U. and Rahman, Z. (2017), "The impact of online brand community characteristics on customer engagement: An application of stimulus-organism-response paradigm", Telematics and Informatics, Vol. 34, No. 4, pp. 96-109.

Jahn, B. and Kunz, W. (2012), "How to transform consumers into fans of your brand", Journal of Service Management, Vol. 23, No. 3, pp. 344-361.

Labrecque, L. I. (2014), "Fostering consumer-brand relationships in social media environments: The role of parasocial interaction", Journal of Interactive Marketing, Vol. 28, No. 2, pp. 134-148. 
Laroche, M., Habibi, M. R. and Richard, M-O. (2013), "To be or not to be in social media: How brand loyalty is affected by social media?", International Journal of Information Management, Vol. 33, No. 1, pp. 76-82.

Laroche, M., Habibi, M. R., Richard, M.-O. and Sankaranarayanan, R. (2012), "The effects of social media based brand communities on brand community markers, value creation practices, brand trust and brand loyalty", Computers in Human Behavior, Vol. 28, No. 5, pp. $1755-1767$.

Lin, H-C., Swarna, H. and Bruning, P. F. (2017), "Taking a global view on brand post popularity: Six social media brand post practices for global markets", Business Horizons, Vol. 60, No. 5, pp. 621-633.

Liu, L., Liu, R. and Chen, J. (2019), "When will consumers be ready? A psychological perspective on consumer engagemen in social media brand communiies", Internet Research, Vol. 29, No. 4, pp. 704-724.

Luo, N., Zhang, M. and Liu, W. (2015), "The effects of value co-creation practices on building harmonious brand community and achieving brand loyalty on social media in China", Computers in Human Behavior, Vol. 48, pp .492-499.

Mathwick, C. and Rigdon, E. (2004), "Play, flow, and the online search experience", Journal of Consumer Research, Vol. 31, No. 2, pp. 324-332.

McAlexander, J. H., Schouten, J. W. and Koenig, H. F. (2002), "Building brand community", Journal of Marketing, Vol. 66, No. 1, pp. 38-54.

McLachlan, S. (2020). "How to increase social meida engagement: A guide for marketers", https://blog.hootsuite.com/social-media-engagement/ (accessed 28 March 2021).

Mollen, A. and Wilson, H. (2010), "Engagement, telepresence and interactivity in online consumer experience: Reconciling scholastic and managerial perspectives", Journal of Business Research, Vol. 63, No. 9-10, pp. 919-925.

Muniz, A. M. and O'Guinn, T. C. (2001), "Brand community", Journal of Consumer Research, Vol. 27, No. 4, pp. 412-432.

Nambisan, S. and Baron, R. A. (2007), "Interactions in virtual customer environments: implications for product support and customer relationship management", Journal of Interactive Marketing, Vol. 21, No. 2, pp. 42-62.

Nambisan, S. and Baron, R. A. (2009), "Virtual customer environments: Testing a model of voluntary participation in value co-creation activities", Journal of Product Innovation Management, Vol. 26, No. 4, pp. 388-406.

Novak, T. P., Hoffman, D. L. and Duhachek, A. (2003), "The influence of goal-directed and experiential activities on online flow experiences", Journal of Consumer Psychology, Vol. 13, No. 1-2, pp. 3-16.

Novak, T. P., Hoffman, D. L. and Yung, Y.-F. (2000), "Measuring the customer experience in online environments: A structural modeling approach", Marketing Science, Vol. 19, No. 1, pp. 22-42.

O'Brien, H. L. and Toms, E. G. (2008), "What is user engagement? A conceptual framework for defining user engagement with technology", Journal of the American Society for Information Science and Technology, Vol. 59, No. 6, pp. 938-955.

Oliver, R. L. (1999), “Whence consumer loyalty?”, The Journal of Marketing, Vol. 63, No. 4, pp. 33-44.

Oliveira, M. and Fernandes, T. (2020), "Luxury brands and social media: Drivers and outcomes of consumer engagement on Instagram", Journal of Strategic Marketing, DOI: $10.1080 / 0965254 X .2020 .1777459$.

Ouwersloot, H. and Odekerken-Schröder, G. (2008), "Who's who in brand communities-and why?", European Journal of Marketing, Vol. 42, No. 5/6, pp. 571-585.

Pitneybowes.com (2019), Critical channels of choice. [online] https://www.pitneybowes.com/content/dam/pitneybowes/us/en/campaign-pages/cmocouncil-report/critical-channels-pb-report-full-data-final-w-commentary.pdf March 2021). 
Pongpaew, W., Speece, M. and Tiangsoongnern, L. (2017), "Social presence and customer brand engagement on Facebook brand pages", Journal of Product \& Brand Management, Vol. 26, No. 3, pp. 262-281.

Schau, H. J., Muñiz Jr, A. M. and Arnould, E. J. (2009), "How brand community practices create value", Journal of Marketing, Vol. 73, No. 5, pp. 30-51.

Shang, R.-A., Chen, Y.-C. and Liao, H.-J. (2006), "The value of participation in virtual consumer communities on brand loyalty", Internet Research, Vol. 16, No. 4, pp. 398418.

Shawky, S., Kubacki, K., Dietrich, T. and Weaven, S. (2020), "A dynamic framework for managing customer engagement on social media", Journal of Busienss Research, Vol. 121 No. December, pp. 567-577.

Simon, C., Brexendorf, T. O. and Fassnacht, M. (2016), "The impact of external social and internal personal forces on consumers' brand community engagement on Facebook", Journal of Product \& Brand Management, Vol. 25, No. 5, pp. 409-423.

So, K. K. F., King, C., Sparks, B. A. and Wang, Y. (2016), "Enhancing customer relationships with retail service brands: The role of customer engagement", Journal of Service Management, Vol. 27, No. 2, pp. 170-193.

Statista (2020a), Active Social Network Penetration in Selected Countries as of January 2020 [online] https://www.statista.com/statistics/282846/regular-social-networking-usagepenetration-worldwide-by-country/ (accessed 10 December 2020).

Statista (2020b), Social Media User Penetration Rate in South Korea in 2019, by Age Group [online] https://www.statista.com/statistics/763718/south-korea-social-mediapenetration-by-age-group/ (accessed 10 December 2020).

Statista (2020c), Number of Social Network Users Worldwide in 2020, by Region [online] https://www.statista.com/statistics/454772/number-social-media-user-worldwideregion/ (accessed 30 December 2020).

Tafesse, W. (2016), "An experiential model of consumer engagement in social media”, Journal of Product \& Brand Management, Vol. 25, No. 5, pp. 424-434.

Van Doorn, J., Lemon, K. N., Mittal, V., Nass, S., Pick, D., Pirner, P. and Verhoef, P. C. (2010), "Customer engagement behavior: Theoretical foundations and research directions", Journal of Service Research, Vol. 13, No. 3, pp. 253-266.

Verhoef, P. C., Reinartz, W. J. and Krafft, M. (2010), "Customer engagement as a new perspective in customer management", Journal of Service Research, Vol. 13, No. 3, pp. 247-252.

Vivek, S. D., Beatty, S. E. and Morgan, R. M. (2012), "Customer engagement: Exploring customer relationships beyond purchase", Journal of Marketing Theory and Practice, Vol. 20, No. 2, pp. 122-146.

Wang, T., and Lee, F. Y. (2020), "Examining customer engagement and brand intimacy in social media context", Journal of Retailing and Consumer Services, Vol. 54, pp. 102035.

Wirtz, J., Den Ambtman, A., Bloemer, J., Horváth, C., Ramaseshan, B., Van De Klundert, J., Gurhan Canli, Z. and Kandampully, J. (2013), "Managing brands and customer engagement in online brand communities", Journal of Service Management, Vol. 24, No. 3, pp. 223-244.

Wong, H. Y. and Merrilees, B. (2015), "An empirical study of the antecedents and consequences of brand engagement", Marketing Intelligence \& Planning, Vol. 33, No. 4, pp. 575-591.

Zaglia, M. E. (2013), "Brand communities embedded in social networks", Journal of Business Research, Vol. 66, No. 2, pp. 216-223.

Zaichkowsky, J. L. (1985), "Measuring the involvement construct", Journal of Consumer Research, Vol. 12, No. 3, pp. 341-352. 